\title{
Fossil fuel divestment and climate change: Reviewing contested arguments
}

\section{Sibylle Braungardt}

Fraunhofer Institute for Systems and Innovation Research ISI, Karlsruhe

And Öko-Institut e.V., Freiburg

Merzhauser Str. 173, 79100 Freiburg, Germany

S.Braungardt@oeko.de

Jeroen van den Bergh

ICREA, Barcelona,

And Institute for Environmental Science and Technology, Universitat Autònoma de Barcelona And School of Business and Economics, and Institute for Environmental Studies, VU University Amsterdam, The Netherlands.

Edifici Z, 08193 Bellaterra, Spain

jeroen.bergh@uab.es

\section{Tessa Dunlop}

Institute for Environmental Science and Technology,

Universitat Autònoma de Barcelona

Edifici Z, 08193 Bellaterra, Spain

Tessa.dunlop@efi.int

Corresponding author: jeroen.bergh@uab.es

\section{Acknowledgements:}

Van den Bergh received financial support from the Spanish Ministry of Science, Innovation and Universities, through the "María de Maeztu" program for Units of Excellence (MDM-2015-0552), and from the European Research Council (ERC) under the European Union's Horizon 2020 research and innovation programme through an ERC Advanced Grant (grant agreement $n^{\circ}$ 741087). 


\section{Abstract}

The strategy of fossil fuel divestment has attracted considerable attention in recent years, particularly in the press and social media. Spearheaded as a movement based on ethical principles, divestment has been suggested to play a potential role in shaping public opinion and policymaking on climate change. The growing size of the movement has prompted debate about the extent of its impact on fossil fuel companies and climate change mitigation efforts. This article investigates the potential effectiveness of the divestment movement according to the end goal of climate campaigners - to bring about a complete break from fossil fuels. We collect and qualify the key arguments as found mainly in the informal debate, and to a lesser extent in the academic literature. This will help readers to make an informed judgement that can contribute to a constructive debate about the effectiveness of divestment. We organize the literature into arguments for and against divestment, and explain how these relate to each other. In addition, we derive suggestions for further research on divestment.

Keywords: Divestment; carbon bubble; fossil-free; stranded carbon; green finance.

\section{Highlights}

- Assesses the debate on the effectiveness of divestment of fossil fuels.

- Seven main pro and contra arguments are identified.

- These arguments draw attention to direct versus indirect effects of divestment.

- Ascertains research needs to further clarify effectiveness of divestment movement. 


\section{Introduction}

Supporting a strategy of fossil fuel divestment - meaning selling off shares in fossil fuel companies by institutions, investment funds or governments - became a rapidly growing social movement after it was promoted in an article by Bill McKibben in Rolling Stone magazine in 2012. McKibben and others had earlier precipitated the movement during the 2007 US primaries through the 'Step It Up' campaign and later in 2008 as part of the 350. org movement ${ }^{1}$. Other notable events have been a highlypublicised student campaign calling on Swarthmore College to divest in the US in 2010, and the more recent 'Keep it in the ground' campaign launched by the UK Newspaper The Guardian in March 2015. Various high-profile organisations have made the decision to divest from fossil fuels, including Rockefeller Brothers Fund, the insurance company AXA, the World Council of Churches and several US universities including Boston, Georgetown University, of Maryland, of Stanford, University of California, of Washington and Yale. Glasgow University was the first European university to commit itself to fossil fuel divestment, followed by many others, notably in the UK and Scandinavian countries. Ireland is set to be the first country to divest after a bill was passed that requires its sovereign wealth fund to sell off its holdings in fossil fuel companies ${ }^{2}$, while there are also calls for divestment action in Australia, India, the Philippines, and South Africa. At some point even the Vatican considered it (The Guardian, 2015a). Not surprisingly, divestment has become a topic of intense debate in the press and social media forums. According to the Fossil Fuel network ${ }^{3}$, as of the third quarter of 2017, the divestment movement has mobilized divestment commitments of approximately US\$5.53 trillion (value of institutions divesting). ${ }^{4}$ In addition, it has raised public and media attention surrounding the role of fossil fuels in climate change issues.

The divestment campaign has strong ethical principles. In its communications strategy, the network of campaigners called Fossil Free, states the divestment movement's bottom line: "divestment is the only moral choice for institutions that care about the economy, society, and planet their students are going to inherit" (Fossil Free, 2014). In this way, the divestment movement has been defined as a "moral entrepreneur' or 'norm entrepreneur' that targets a particular behavior (carbon pollution) as morally corrupt, and uses this frame to change attitudes about climate change mitigation (Ayling and Gunningham, 2015). In line with this, the intended threat to fossil fuel companies relies on the stigmatization process ${ }^{5}$, with the ultimate goal of bringing about a complete break with fossil fuels to stop climate change (Ayling and Gunningham, 2015; Beer, 2016). The IPCC's latest Synthesis Report established that there is a clear link between the burning of fossil fuels and the climate system (IPCC,

\footnotetext{
${ }^{1}$ There are various accounts of the exact beginning of the most recent fossil fuel divestment movement. According to an article in the New York Times it "begun on the campus of Swarthmore College in Pennsylvania in 2011" http://nyti.ms/1Sh7ngl. We do not intend to provide a detailed historical account of the divestment movement here. See instead: http://sites.middlebury.edu/divest/ourcampaign/history: http://bit.ly/2fU26yK; http://www.ozy.com/flashback/the-history-of-campus-divestments/32620;

https://www.theguardian.com/environment/2015/may/19/the-rise-and-rise-of-the-fossil-fuel-divestmentmovement. Of course, divestment campaigns have a longer history, the most famous one being motivated by South African apartheid (discussed at various points later in the text).

${ }^{2} \mathrm{https}$ ://www.theguardian.com/environment/2018/jul/12/ireland-becomes-worlds-first-country-to-divestfrom-fossil-fuels

${ }^{3}$ http://gofossilfree.org/commitments/

${ }^{4} \mathrm{~A}$ basic problem here is that so far divestment is still largely in the realm of pledges. In addition, numbers like these numbers do always not represent actual investment. The following disclaimer in Arabella Advisors (2016, p. 4) is noteworthy in his respect: "Arabella measured the total assets (or assets under management for financial institutions) of institutions that committed to divest. As such, asset sizes reported do not represent sums divested from fossil fuel companies. Rather, asset sizes represent total assets held by institutions that have committed to divest." Another consideration is that $20 \%$ of institutions declined to report on their assets, meaning that the US\$5 trillion figure is significantly lower than the full scale of commitments made (Arabella Advisors, 2016).

${ }^{5}$ https://www.theguardian.com/environment/2015/mar/09/10-myths-about-fossil-fuel-divestment-put-to-thesword
} 
2014). It estimates that the associated emissions of carbon dioxide $\left(\mathrm{CO}_{2}\right)$ contribute about $78 \%$ of the total increase in global GHG emissions between 1970 and 2010.

The discourse on divestment has mostly taken place in public media and on the Internet while it is receiving increasing attention in academic outlets. The aim of this article is to offer an overview and academic qualification of the main views in the debate. This then allows us to identify unresolved questions that deserve attention in academic research. To this end, in sections 2 and 3 we discuss the main arguments for and against divestment as found mainly in the informal debate on divestment, and to a lesser extent in the academic literature, and qualify these. In Section 4 we indicate which for (F) and against (A) arguments relate to, or contradict, each other, and discuss to what extent fossil fuel divestment can be expected to be effective in terms of reducing $\mathrm{CO}_{2}$ emissions, accounting for the various mechanisms identified in the debate.

The academic and informal or grey literature discussed here tends to focus on either pro or contra arguments. Moreover, the existing scientific literature explores various environmental, legal, social and financial aspects regarding fossil fuel divestment. As a result, readers may not find it easy to overlook all the subtle and different arguments underlying the pro and contra positions. Our paper is the first to collect all of them, thus offering a useful contribution to the debate. It provides a comprehensive overview of the main arguments discussed in the public media and analyses to what extent the scientific literature supports or opposes the views presented. We further provide suggestions for academic research that can help to get a clearer picture of the effectiveness of divestment.

\section{Arguments for divestment}

\section{F1. Its moral-political stance can trigger debate and spur climate action}

Divestment combines the scientific evidence on climate change with the moral argument that the "fossil fuel industry's business model is greatly inconsistent with keeping climate change below disastrous levels" (Lenferna, 2015; The Washington Post, 2015). Some attribute nearly two-thirds of historical carbon dioxide and methane emissions to 90 entities, which include the major fossil fuel producers (Heede 2013). In this respect, the movement primarily acts as a norm entrepreneur, somewhat comparable with the anti-slavery (abolitionist) movement starting around 1830 in the US, or the international anti-apartheid or boycott (i.e. divestment) movement from the 1960s to the 1990s opposing apartheid institutions in South Africa. One report says that "The fossil fuel divestment movement, now on more than 1,000 American college campuses, aims at capturing a generation of college students as lifelong climate activists."

The sheer impact of the divestment movement - in terms of growth in numbers, amount divested and speed - can possibly increase pressure on voters and politicians to take action. According to one source, divestment "may convert major institutions and groups to take stands that they otherwise would not have taken (and so, again, make future change more likely)" ${ }^{\prime \prime}$. A large divestment movement provides an avenue to articulate the public interest and can influence government policy (Roberts 2015). According to Linnenluecke et al. (2015), there is already a confluence between policy and organisational responses that will lead to more action on climate change - namely more stringent policy action and grassroots support for a shift towards more sustainable models of doing business. Likewise, Gunningham (2017) points out that the public support created by the divestment movement may be the foundation on which the successful implementation of international agreements and effective top-down actions can built. Bergman (2018) highlights that the discourse has revitalized the

\footnotetext{
${ }^{6}$ http://www.prindlepost.org/tag/divestment.
} 
environmental movement in some countries (notably the UK and USA) as it has "precipitated mobilisation, political and financial impacts, as the notions of divestment entered different public spheres, attracting supporters and causing demands from investors and new conversations among financiers." Those who are a part of the movement believe that divestment is bringing about a new paradigm of climate justice attached to global civil society platforms, stemming mainly from student activism (Bratman et al., 2016). While the issue of whether historical divestment campaigns, such as those triggered by apartheid in South Africa and tobacco in the US, affected the financial performance of the companies in a significant way is still under debate (see Section A3 for more details), there is consensus that they did influence policy change (Davidson and Kaufman, 2015; Leber, 2015). Murtha (2015) states that by focusing attention on the oil industry's climate-destroying business plan, "campaigns seek to delegitimize the industry and create the political space for policymakers to put a price on carbon pollution and make the necessary investments in clean, renewable energy instead of giving massive subsidies to the fossil fuel industry."

In a public debate at $\mathrm{MIT}^{7}$, Don Gould, a proponent of divestment and chief investment officer for Gould Asset Management, agreed that shareholder engagement can be a useful mechanism. However, he pointed out that it is questionable to expect a coal producer to stop producing coal due to shareholder engagement. He suggests instead that divestment is not aimed solely at fossil-fuel companies but "at the policymakers who have to formulate a policy that will provide for a habitable planet". In the same vein, Naomi Klein has said that divestment is a process which delegitimises the fossil fuels sector because it is not a legitimate business model: "once we collectively say that and believe that and express that in our universities, in our faith institutions, at city council level, then we're one step away from where we need to be, which is polluter pays" ${ }^{8}$.

Many proponents focus on the moral argument posed by divestment more than on the practical effects on companies, markets and emissions levels. "We all have a moral obligation", states Valerie Rockefeller Wayne, chair of the Rockefeller Brothers Fund ${ }^{9}$. Another view combining both moral and goal-oriented angles is that "... the more we can make climate change a deeply moral issue, the more we will push society towards action ${ }^{10 "}$. Another moral argument arises from linking divestment to energy justice (Healy and Barry, 2017).

\section{F2. Stigmatizing the fossil fuel industry may diminish its power over policy}

Some view fossil fuel companies as central to our fossil fuel addiction. McKibben articulates the influence of fossil fuel companies in phrases such as "the power of the fossil-fuel industry", "the fossilfuel industry's political standing" and "How to stop the fossil fuel industry from wrecking our world"' McKibben $(2012,2016)$. Others agree that "These companies are culpable for the carbon emissions condemning us to global climate change and sea level rise"11, and "... we need to loosen the grip that coal, oil, and gas companies have on our government and financial markets ... It's time to go right to the root of the problem - the fossil fuel companies themselves [...]"12.

\footnotetext{
${ }^{7}$ http://newsoffice.mit.edu/2015/debate-fossil-fuel-divestment-0410

${ }^{8} \mathrm{http}: / /$ www.theguardian.com/environment/2014/oct/08/fossil-fuel-divestment-a-brief-history.

9 http://www.theguardian.com/environment/2015/mar/27/rockefeller-fund-chairman-moral-duty-divestfossil-fuels

$10 \mathrm{http} / /$ gofossilfree.org/usa/wp-content/uploads/sites/6/2015/03/FossilFreeFrequentlyAskedQuestions.pdf However, climate change has been assessed as a type of issue that fails to generate strong moral intuitions (Markowitz and Shariff, 2012).

${ }^{11}$ https://onespark.com/festival/2015/projects/fossil-fuel-divestment-at-unf

${ }^{12} \mathrm{http}$ //gofossilfree.org/usa/wp-content/uploads/sites/6/2015/03/FossilFreeFrequentlyAskedQuestions.pdf
} 
Stigmatizing the fossil fuel industry may diminish its power over policy (Grady-Benson 2014). There is strong evidence that these companies use lobbying power to receive favourable conditions, including indirect subsidies, and to postpone the implementation of climate regulation (Brulle, 2014; Davidson and Kaufman, 2015). Fossil fuel companies have spent significant amounts of money on lobbying against climate legislation. Oxfam estimates that in 2013, the fossil fuel industry spent approximately US\$213 million lobbying US and EU decision-makers (Stoddart, 2014). This study claims that "despite some steps in the right direction to tackle climate change, a 'toxic triangle' of political inertia, financial short-termism and vested fossil fuel interests blocks the transition that is needed". Fossil Free MIT (2014) claims that the fossil fuel industry has funded disinformation campaigns that "confuse the public, sabotage science, and slander scientists". John Sterman, the Jay W. Forrester Professor in Computer Studies at the MIT Sloan School of Management, said in a public debate ${ }^{13}$ that MIT "must take a stand" and that fossil-fuel companies "continue to fund deniers, undermine the science, confuse the public, and delay action - actions antithetical to the values of MIT." A book by Oreskes and Conway (2010) provides a historical account of how some companies have spread doubt and confusion about climate change. ${ }^{14}$ Supran and Oreskes (2017) analyse the climate change communications by Exxon Mobile and conclude that ExxonMobil misled the public. Ayling (2017) points out that the fossil fuel industry's efforts to delegitimize the movement by challenging the concept of divestment and by discrediting both divestment campaigners and divestors reflects the fact that the industry takes the contest very seriously.

An additional argument to target oil and gas companies with divestment campaigns is that this could stimulate them to undertake more efforts to develop climate solutions. For example, they could be "developing carbon capture and storage (CCS) quickly ... it is not rocket science"15. Not all divestment proponents, however, regard CCS as a genuine or definite climate change solution.

\section{F3. The exploration capacity of fossil fuel companies may be reduced}

While the divestment movement typically focuses on the political statement of divestment, a potentially strong argument in favour of divestment could be that it may limit the capacity of companies to undertake further fossil fuels exploration due to the effects of reduced shareholder investment, earnings potential and willingness of banks to provide loans. As a consequence, this could reduce the global supply of fossil fuels, triggering higher prices, and, in turn, lower GHG emissions. Many on both sides of the debate, however, are not convinced about the likelihood of this outcome, arguing that there is a high degree of uncertainty surrounding the effect of divestment on investor behaviour, investor portfolios and the reaction of oil and coal companies (Davidson and Kaufman 2015). It is possible, for example, that reduced demand for fossil fuels stocks brought about by divestment action could lower share prices and trigger a market correction if investors then take advantage of cheaper share prices. Moreover, according to Baker et al. (2003) stock prices have a relatively strong impact on the investment of firms that depend heavily on external equity, which characterizes fossil fuel companies.

\footnotetext{
${ }^{13}$ http://newsoffice.mit.edu/2015/debate-fossil-fuel-divestment-0410

14 See further http://www.washingtonpost.com/opinions/the-fossil-fuel-industrys-campaign-to-mislead-theamerican-people/2015/05/29/04a2c448-0574-11e5-8bdac7b4e9a8f7ac_story.html?postshare $=4861432993374444$

15 http://www.theguardian.com/environment/2015/jun/04/former-shell-chairman-advocates-fossil-fueldivestment?utm_medium=twitter\&utm_source=dlvr.it
} 


\section{F4. Divestment can moderate systemic financial risks of a 'climate bubble'}

In recent years, the impact of climate policy on investments in fossil fuel exploration has received increased attention from academic researchers (McGlade and Ekins, 2015), the financial sector (Carbon Tracker Initiative, 2011; HSBC 2013; The Guardian, 2014) and the policy sphere (Ambrose, 2015; Evans-Pritchard, 2015; European Green Party, 2014). Investment in fossil fuel exploration activities and extraction facilities become so-called "stranded assets" if climate policy achieves its goals (European Green Party, 2014). Including the impact of climate change itself on asset values, the expected 'climate value at risk' of global financial assets is estimated to be US\$2.5 trillion according to one study (Dietz et al., 2016) and in the range of US\$1-4 trillion according to another (Mercure et al., 2018).

Based on research by the Potsdam Institute for Climate Change, the Carbon Tracker Initiative calculates that limiting the chance of exceeding $2^{\circ}$ Celsius warming to $20 \%$ means that $\mathrm{CO}_{2}$ emissions cannot exceed $565 \mathrm{Gt}$ in the 40 years between 2010 and 2050 (Carbon Tracker Initiative 2011). However, the Carbon Tracker estimates the carbon potential of the Earth's known fossil fuel reserves as five times this, with $65 \%$ corresponding to coal, $22 \%$ to oil and $13 \%$ to gas. If climate policy were to be implemented to achieve the $2^{\circ}$ Celsius target, investors would face the risk that up to $80 \%$ of declared reserves by the world's largest fossil fuel companies become stranded assets. This has been referred to as a carbon bubble. It has become a central argument for the divestment movement, instigated by (McKibben, 2012): “... the aim of those advocating for divestment and carbon transparency is to create awareness of the carbon bubble which might channel investment funds into other areas such as alternative energy."

Beside the long-term financial risks, a recent study by Henriques and Sadorsky (2017) finds that portfolios which divest from fossil fuels and invest in clean energy perform better than those with fossil fuels. Indicative for stranded assets is also that large insurance companies, notably from Europe but less so from the USA and UK, are already limiting insurance for coal companies. ${ }^{16}$

\section{F5. Divestment can stimulate re-investment in low-carbon technologies}

Divesting from fossil fuels may involve a shift of investment to low-carbon solutions (Arabella Advisors, 2016; Divest-Invest Global Movement, 2014; Green America, 2013). The positive effect of divestment is augmented when money is reinvested in clean energy technologies and energy efficiency, benefiting the application and innovation of these industries (such as stimulating discovery in battery technology or alternative power generation technologies) (Linnenluecke et al., 2015). The economist Nicholas Stern recently said that the "most effective divestment strategy did not just look to divest from fossil fuel companies, but to positively keep stocks or invest in companies that were taking responsible action on climate change." (The Guardian, 2015b).

Arabella Advisors (2016) claims that thanks to divestment commitments, more capital is flowing to climate solutions, but does not back this up with any evidence. They state that many institutions which have pledged divestment have at the same time promised to increase investments in low-carbon options.

On the whole the divestment movement has, though, not paid much attention to the issue of lowcarbon re-investment - even though one might claim that it is implicit in the message to move away from fossil fuels. This may be because the shift to renewables diverts attention away from the core political message that fossil fuels are the central problem in climate change. Another explanation is that a focus on specific renewable energy investment options could complicate the message and risk

\footnotetext{
${ }^{16} \mathrm{https}: / /$ www.theguardian.com/environment/2018/dec/03/insurers-in-uk-and-us-lagging-behind-indivesting-from-coal-report-finds
} 
debate, potentially reducing the unity of, and support for, the divestment movement. In the words of Davidson and Kaufman (2015), proponents should "focus on the political impact of divestment [see F1] , and not get distracted by the economics of divestment" - that is, the reallocation of investments.

\section{F6. Divestment addresses an emerging legal responsibility of investors to cope with climate change risks}

Some advocates of divestment contend that divestment is not only lawful but that it is becoming a duty (Richardson, 2017). In the first case of its kind, university students in 2014 brought Harvard University to court by alleging the mismanagement of charitable funds and "intentional investment in abnormal activities" for not divesting from fossil fuel stocks. Using the 'atmosphere as public trust' theory of litigation as a model, the case has shifted the divestment debate to look at whether public and charitable institutions owe their beneficiaries a duty beyond just maximizing financial benefits when making investment decisions (Franta 2017). Sarang (2016) argues that fiduciary duties are compatible with divestment because of the long-term risks of climate change and stranded assets and calls for legal reform mandating that public and charitable institutions consider the risk climate change poses to their portfolio and to human well-being and divest from companies whose business plans threaten the climate (Sarang, 2016).

\section{F7. Divestment as an opportunity to involve and educate young people}

Some university practitioners see the divestment movement as a chance to educate students informally about climate action and teach them critical thinking skills through engaging with the movement. More generally, the divestment movement, with many actions at universities (see opening of the article) has raised awareness of divestment in higher education. Beer (2016) found that: "The process of deciding to divest was framed not as a contentious process to be resisted, but as something that colleges were tasked with doing - educating young people." Furthermore, an argument in favour of divestment is that it may be able to provide a structure for developing and encouraging 'social learning' and bottom-up participation that are an important element of political change - which other climate mitigation initiatives such as the Kyoto Protocol have so far failed to achieve (Linnenluecke et al., 2015; Rowe et al., 2016). Others think that universities should learn how to invest responsibly and show to others that "money management is not separate from its moral and environmental consequences" (Cleveland and Reibstein, 2015). Stephens et.al. (2016) review strategic financial decisions in various higher education to analyse the role of universities in promoting a more sustainable society.

\section{Arguments against divestment}

\section{A1. It is symbolic and without economic impact translating in reduced $\mathrm{CO}_{2}$ emissions}

Many divestment campaigners are motivated by the symbolism of divestment ${ }^{17}$. This suggests that the concept of divestment should not be taken too literally as its main purpose is to make a political statement, independent of concrete economic and environmental implications. Some suggest that symbolic actions like divestment have the potential to exert serious impacts (Ayling and Gunningham, 2017), namely by influencing democratic political processes (Franta, 2014). Others argue that divestment is unlikely to have considerable financial effects on fossil fuel-related GHG emissions for two main reasons (Ansar et al., 2013): investors are unlikely to respond in large numbers; and indirect,

\footnotetext{
${ }^{17}$ http://www.toronto350.org/divestment-symbolism
} 
systemic effects, such as other investors buying the divested shares in fossil fuel companies, may undo any first-order effect. For this reason divestment has been judged as a 'silver bullet' or a fake and magical solution ${ }^{18}$.

Given that investors are generally driven by profit-making, few would turn away from fossil fuels if it means sacrificing a return on investment or facing increased financial risk. However, one can expect some entities to divest when the share value of fossil fuel investments falls or when fossil fuel stocks produce meagre returns compared with other portfolio assets. If the Paris climate agreement results in coordinated, stringent climate policies around the world, then fossil fuel investments would become stranded assets, triggering automatically divestment (see F4). But such climate action is still far from becoming a reality, and there is a risk, as Gapper (2015) states, that we "make a grand symbolic gesture and carry on as normal", or, in the words of Dowlatabadi, "divestment may end up being greenwash" (Lavoie, 2015). On the other hand, Weber et al. (2017) claim that divestment announcements have a statistically significant negative impact on the price of fossil fuel shares, based on an analysis of over 20 announcements covering 200 publicly traded fossil fuel companies. But it is fair to say that they only report temporary effects and do not provide insight into macro-level and longer term consequences. More generally, Hong and Kacperczykb (2009) find that "sin stocks" - i.e. publicly traded companies involved in producing alcohol, tobacco, and gaming - are less held by norm-constrained institutions such as pension funds and have relatively high returns. They also stress that ethical norms do not necessarily affect stock prices and returns negatively. On the other hand, there is also evidence that socially responsible investors are willing to accept suboptimal financial performance to achieve socialethical goals (Renneboog et al., 2007), causing security prices to deviate from values defined by costs and profits (Morck et al., 1990).

While divestment could hamper the extraction capabilities of fossil fuel companies, it is also possible that divestment will not significantly impact share values or return on investments. The capacity of fossil fuel companies to invest in exploration technologies and activities depends on access to capital. Capital can be generated by issuing stocks and bonds. Even assuming a drastic increase in divestment from fossil fuel companies, if investors are willing to buy the divested shares then the price of the shares will remain largely unchanged with no economic impact on the fossil fuel company (Ansar et al., 2013). In addition, money divested from fossil fuel companies and reinvested in banks will very likely end up in funding such companies again (Ritchie and Dowlatabadi, 2015b). Even if divestment did occur on a large scale and succeeded in effectively reducing share prices, then the investors willing to purchase such shares might earn still good (or even higher) returns, thus defeating the aim of divestment (Davies and Van Wesep, 2016). Similarly, the energy reserves would most likely be bought and extracted by other companies. This last point is, however, contingent upon the demand outlook for fossil fuels and the introduction of more stringent climate policy.

\section{A2. Focus on fossil fuel companies neglects the systemic nature of emissions}

From a systems perspective, all production and energy activities, and consumers, are connected. The blame for our dependence on fossil fuels cannot be squarely placed on energy companies. Rather, the discovery of fossil fuel supplies in the Earth's crust followed by a long historical process of industrialization have resulted in an economic trajectory dependent on fossils fuels. As pointed out by Moss (2017), the links between emitters and the harms that emissions cause is often not a straightforward relationship, and an agent's moral responsibility depends on where the actor is placed in this causal chain. Despite the rapid growth of the renewable energy sector and increased energy efficiency, even the most optimistic scenarios expect fossil fuels to play a major role in our future energy mix (IEA, 2013-2016; Krey et al., 2013; Clarke et al., 2014). Some divestment critics therefore argue that the immediate solution is not to blame these companies or reduce their capacities. In fact,

\footnotetext{
${ }^{18} \mathrm{https}$ ://risk-studies-viewpoint.blog.jbs.cam.ac.uk/2015/01/28/the-fossil-fuel-divestment-campaign-whatrole-does-it-play-in-addressing-emerging-carbon-risk/
} 
one might as well argue that energy equipment-producing industries and consumers who buy their products are the core problem.

In the original plea for fossil-fuel divestment, McKibben (2012) argued for a price on carbon stating that "The five biggest oil companies have made more than [US] $\$ 1$ trillion in profits since the millennium ... Much of that profit stems from a single historical accident: Alone among businesses, the fossil fuel industry is allowed to dump its main waste, carbon dioxide, for free. Nobody else gets that break." This can be seen as blaming and shaming of the fossil fuel industry ${ }^{19}$. But singling out this industry is simplifying and misrepresenting the complex consumption-and-production system of which it is an integral part. From this perspective, some opponents see divestment not as support for climate policy, but as an inferior alternative to a more adequate strategy of applying systems control through effective policies.

Moreover, even if one can single-out companies that are blocking environmental regulation in many industries, including some firms in the fossil fuel industry, this does not necessarily mean one should punish the entire industry of which they are part. This would deny the diversity among companies and their strategies regarding lobbying, advertisement and resistance against information about climate change ${ }^{20}$.

From a practical perspective, Ritchie and Dowlatabadi (2015a) have found that institutional investors are limited in their ability to reduce their exposure to greenhouse gas emissions and purchase carbonneutral stocks. Firstly, equity holdings of fossil fuel companies have different characteristics than viable investments in renewable energy projects or companies. In comparison to fossil fuels, renewable energy generation assets have high initial capital expenditures and relatively low ongoing operational expenditures, such that switching to renewable energy assets requires significant changes to institutional investment policy. Secondly, fund managers can easily adhere to divestment principles by shifting investments into sectors that are not carbon neutral, for example, the financial services and car companies. Third, if investors are to divest and re-invest in stocks that are deemed sustainable, then there needs to be fundamental changes made to investment policies and expectations. This is because fund managers who are required to meet a certain dividend yield and with low risk tolerance will find it difficult to replace their oil and gas equities with green companies. Furthermore, it is likely that there is a limited supply of 'green' stocks to replace fossil fuel stocks. Ritchie and Dowlatabadi (2015c) found, though, that investment in fossil fuels by some universities could be replaced by certain greener investments consistent with divestment without a serious impact on income.

Davies and Van Wesep (2016) point to another practical problem of divestment related to executive remuneration. The authors argue that divestment is a perverse incentive for company CEOs to succeed in securing a low share price at the time they are awarded stock grants or options. This is because the lower the share price, the higher the number of company stock they are likely to be awarded. The authors explain: (These facts suggest that) "it is stock returns, not stock prices, that drive executive pay, meaning that it is in executives' financial interests to ignore divestment campaigns, at least until they want to sell their shares".

\footnotetext{
${ }^{19}$ It is fair to say that McKibben continued the cited statement with discussing the importance of carbon pricing, recognizing that consumers and producers need to demand less oil. However, this can be seen as inconsistent with his statements "Alone among businesses" and "Nobody else gets that break". We all get that break: producers and consumers equally avoid paying for the external/social cost of $\mathrm{CO}_{2}$ emissions; and the fossil fuel industry does not emit (or dump) the waste, as this is done later in the production-consumption chain by the fossil fuel users.

${ }^{20}$ For example, here one can find a list of the five so-called "worst offenders" among coal, oil and gas companies: http://gofossilfree.org/usa/wp-content/uploads/sites/6/2015/03/FossilFreeFrequentlyAskedQuestions.pdf

See also distinct views of European versus some US companies on carbon pricing: http://thinkprogress.org/climate/2015/06/03/3665618/oil-companies-want-carbon-price
} 
An alternative to divestment is that the Paris climate agreement induces governments to implement effective climate policies (notably carbon pricing), that drives non-voluntary action and divestment. However, this would require international coordination of national climate policies, something which was not part of the Paris agreement. The implementation of systemic policy does not necessarily overlook solutions directed at the supply side, including the fossil fuel industry. Indeed, as Sinn (2012) argues, to avoid energy and carbon rebound, we need a supply policy. This could be a carbon price or a cap on oil supply, and thus exploration. For this policy to be effective, governments would need to agree on such a cap to trigger large-scale divestment across the globe.

\section{A3. A potential negligible effect on public support for climate policy}

The scientific evidence on climate change has so far not generated sufficient worldwide support for stringent policies in all countries. It has so far not been demonstrated that the divestment movement can make a measurable difference. A major problem is political gridlock at national (notably US) and consequently international (negotiations climate agreement) levels, due to climate sceptics/deniers and those disinterested in climate policy. It is not clear whether these groups would change their minds if given the direct option to divest. Hope (2015) suggests the divestment movement, in particular The Guardian campaign, is preaching to the choir. He states that climate deniers might regard divestment as a typically left-wing issue that only self-reinforces their own position. In other words, divestment might have a politicizing and polarizing effect.

Some have argued that divestment is largely ineffective simply because a significant number of educational institutions had already divested from fossil fuel companies long before the divestment movement picked up steam after 2012 (Beer, 2016). This is because many universities had already aligned their investment portfolios according to environmental concerns and sustainability values. One college president in Beer's qualitative (2016) study noted: "The board agreed that we should invest in things that support our values rather than divest from things. So by the time the fossil fuel divestment campaign began, we were already virtually out of it."

Finally, the divestment strategy has been compared to the trade and investment sanctions imposed on South Africa to fight apartheid in the 1970s and 1980s (Tutu, 2014). However, this analogy is questionable because this concerned a national policy. Climate change, on the other hand, represents, a global public goods issue that fundamentally differs from a human-rights issue within a single country. For more discussion of differences and similarities see Hunt et al. (2017). Nevertheless, something can be learned possibly from ex-post analysis of how companies, markets and politicians responded to divestment calls and actions. The evidence of such effects is mixed: e.g., Posnikoff (1997) and Kuman et al. (2002) find a positive effect of (announcing) divestment (called "withdrawal") by a firm on its returns, Meznar et al. (2017a) a negative effect, while Hong Teoh et al. (1999) find little effect on firms or (South-African) markets. Meznar et al. (2017b) discuss these seemingly contradictory findings and attribute differences to the effect of timing of withdrawal announcements.

\section{A4. Risk of backfire by drawing attention away from more effective climate action}

Climate change mitigation requires policies that steer consumers and producers away from highcarbon producing activities. While divestment may prove to be a catalyst for policy action, it is essential that climate action moves beyond divestment, triggered by climate policies that are effective in terms of reduction of emissions. There is new impetus for the implementation of such policies in the wake of the Paris agreement, although we cannot be too optimistic about realizing stringent, effective and consistent measures in all countries yet.

Concerns have been raised that the high degree of attention focused on the divestment movement may crowd out other, more practical and effective action against climate change (Hope, 2015; Stavins, 
2014; Tollefson, 2015; Wolak, 2014). Similar concerns have been raised by Exxon Mobile (2015), stating that divestment is a divisive and counterproductive diversion from the search for genuine solutions to the economic and environmental challenge we face. Moreover, the divestment movement may generate a false sense of security that our society is making progress in reducing GHG emissions, even when divestment turns out to be ineffective. This false feeling might reduce interest and support for effective policies. Such negative spill-overs in environmental behaviour have been documented by psychologists (Truelove et al., 2014). However, based on a network text analysis, Schifeling \& Howard (2017) find that liberal policy ideas (such as a carbon tax), which had previously been marginalized in the U.S. debate, gained increased attention and legitimacy through the divestment debate.

The main teachings about climate policy, notably in courses comprising environmental and ecological economics - which are integral part of most bachelor- and master-level degrees in higher education within the environmental sciences field - currently argue strongly in favour of carbon pricing, specifically through a carbon tax or emissions trading, and direct support such as subsidies for promising but still expensive technologies. Student actions would be consistent with their syllabi if they asked their universities to implement carbon taxes or emissions trading on campus, and indeed some campuses have done this (http://carbon.yale.edu/project-overview). These experiments could help inform further research in the area. In defence of divestment, however, the implementation of carbon taxes or emission trading on campus and divestment activism are not mutually exclusive strategies, and universities could potentially do both.

\section{A5. Inconsistency: change others not yourself, and continue carbon-intensive consumption}

Here we consider the behavioural inconsistency where individuals or entities divest but continue to use high-carbon energy as in the past. Instead, it would be more consistent to divest from oil and simultaneously refrain from consumption that directly or indirectly depends on oil. Wolak (2014) states that fossil-fuel companies continue to produce coal and oil "because we demand them, to heat our homes, to drive our cars, to fly in our airplanes ... Divestiture does nothing to address that problem ... As long as demand is still there for the fossil fuels, the greenhouse-gas emissions will exist, regardless of who owns the assets" 21 . If this is the case, a classic economics principle may be turned on its head: that private vices lead to public virtues ${ }^{22}$. This idea is that selfish individual interests can bring about a collective public benefit. In the case of divestment, it may be that the private virtue of divesting may lead to the public vice of lesser mitigation of harm (Davies and Van Wesep, 2016). As pointed out by Moss (2017), to "resolve the inconsistency, an institution could either reduce all of its activities that cause emissions or simply not divest".

Another inconsistency is to point the finger at others by asking them to divest, without oneself experiencing the economic or financial consequences of divestment. One could avoid such inconsistencies by asking, for example, from students demanding universities to divest that they avoid holiday flights or pay a higher tuition fee to compensate the university in the case of lower returns on investment. Similarly, one could ask pension-right holders in favour of divestment to give up a part of their pension to compensate for any lower return on investment. When faced with such tangible personal consequences, it is likely that fewer people would render their support to divestment action.

\section{A6. It is questionable to apply subjective norms to other people}

What role do large institutions play, including pension funds or university endowments, in making investment decisions on behalf of their individual members and constituents, who have diverse

\footnotetext{
${ }^{21} \mathrm{http} / / /$ newsoffice.mit.edu/2015/debate-fossil-fuel-divestment-0410

${ }^{22}$ An idea documented in Mandeville (1714)'s manuscript, Private Vices, Publick Benefits
} 
interests? If a society decides on certain norms in a democratic way and translates these into concrete regulatory policies, then all citizens are held by it. But why should particular norms, such as divestment, that are not supported by the majority, be adopted under the pressure of a sub-group in society, without any democratic process involved?

One alternative is offering choice options. To take the example of a pension fund, it would preferable to start a non-fossil fuel pension fund where members could elect, on an individual basis, whether they would like to participate and shift their assets to that fund ${ }^{23}$.

With regard to universities, Bowen (2015) formulates a particular problem: "Taking an institutional stand on political issues of many kinds threatens the primary educational mission of the university, which is to be avowedly open to arguments of every kind and to avoid giving priority to partisan or other political viewpoints. The university should be the home of the critic - indeed, the home of critics of many different persuasions - not the critic itself." In this sense, universities cannot be compared with other organisations that have overt political missions, such as NGOs. This does not mean, however, that universities are not bound by commonly accepted positions on topics such as human rights or child labour in their investment strategies. On more vigorously debated issues, however, taking such a political stand would be less convincing and difficult to defend.

Some argue that rather than divestment, a more effective way of tackling carbon emissions would be to pressure companies from the inside out. This could be done through pressuring the board or compensation committee to invest in cleaner technology and sequestration alternatives, and take a long-term approach to corporate sustainability and executive compensation (Linnenluecke et al., 2015). The authors point out, however, that influencing company leadership in a shareholder role is not guaranteed and may only result in short-term fixes.

\section{A7. Representative role of institutions and unwanted societal effects}

The main role of investment portfolios is to assure the availability of capital to support the mission of institutions. For example, endowments support universities in providing high-level research and education. The main goal of pension funds is to ensure a certain level of financial security in the future pensions of their clients. From a financial point of view, if an institution makes investments based on moral or political arguments, the divestment is likely to have negative effects on the financial returns of its investment portfolio. If financial losses are significant, they may affect the core task of the institution, raising another ethical question. If a university deliberately chooses to risk losing money through divestment, for example, it may simultaneously be foregoing the opportunity to start a new research and education programme, such as on climate policy. A university must weigh up potential financial risks and climate gains from divestment as well as the effects it may have on its primary role as an institution. Incidentally, Plantinga and Scholtens (2016) and Trinks et al. (2018) find that fossilfree portfolios do not significantly underperform compared with an unconstrained market portfolio.

There is debate on the potential effect of divestment on society as a whole, especially the Global South. Critchlow (2015) states that "without a viable large-scale renewable alternative on the horizon, capable of replacing oil, gas and coal in the energy mix, the consequences of starving the fossil fuels industry of investment are reckless and potentially disastrous." He sees as a main undesirable social consequence that "This predominantly Western, middle-class group [the divestment movement] would condemn billions of people in the developing world to lives of misery with no hope of improvement. In Critchlow's scenario, the divestment movement would be depriving the world's poor of the fundamental human right to affordable energy, just to placate their own collective conscience. However, this view misses three important points. First, the argument can be used as ammunition against any climate strategy or policy. Second, the poor are likely to be hit harder by climate change in

\footnotetext{
${ }^{23}$ http://action.shareaction.org/page/s/give-me-a-fossil-free-option
} 
the absence of climate action, both in rich and poor regions. Third, the affordability and availability of renewable energies have improved significantly over the past decade, which has generated rapid deployment and consumption of these energy sources in both developed and developing countries.

\section{Conclusions}

This article has collected the various pro- and contra-arguments regarding the effectiveness of divestment and has qualified each of these. This final section summarizes the findings and adds comments regarding the overall picture that emerges. We do not claim to offer a definite answer as we intended to maintain as much objectivity as possible, which means weighing up the arguments is virtually impossible. Table 1 lists the various arguments, indicates how they relate to opposing views, and proposes a research agenda to advance the debate on the effectiveness of divestment.

The complex divestment debate raises many practical and ethical issues. It is difficult to arrive at a simple conclusion about whether divestment can reduce GHG emissions, due to multiple secondary effects as well as market and political uncertainties. For a fruitful debate on divestment, it would be good to make a clear distinction between the direct and indirect effects of divestment on GHG emissions. While critics of the divestment movement tend to emphasize that direct effects of divestment on financial and economic performance of fossil fuel companies or even on GHG emissions reduction in the economy are very limited, many proponents of the movement do not consider these effects to be a relevant outcome of divestment. By contrast, they regard as its main aim to create increasing awareness of the need for climate action and increase citizen and voter support for climate policy. As highlighted in arguments F3, F5, A1 and A2, the direct effects of divestment on GHG emissions are likely to be insignificant insofar as fossil fuels remain economically attractive. That is, in the absence of a concrete and attractive global carbon price, encouraging divestment through campaigns is unlikely to be an effective strategy to reduce GHG emissions. However, divestment can have considerable indirect effects (F1, F2). In particular, it can create a broader social awareness and support for effective climate policy (F1) by playing the role of a norm-changing and conscious-raising actor, drawing on media attention and public support from prominent organisations and individuals that promote strict regulation of GHG emissions.

Taking the positive indirect effects on emissions reduction into account, divestment campaigns hold potential as enhancing the acceptance of and support for effective climate policies. However, the extent of this potential will depend on issues that are still uncertain and need further research, namely: the possible polarization effect of divestment pleas on proponents and opponents of climate policy (A3); the risk of divestment crowding-out other actions and creating more emissions as an unintended second-order effect (A4); and the unwanted social (including distributional) effects if radical divestment reduces profits and causes losses in investment portfolios instead of fostering a smooth socio-technical transition to a low-carbon economy (A7). From this perspective, the likely financial, economy-wide and social impacts of divestment (F4) need further investigation.

In sum, while divestment campaigns are unlikely to have a significant direct impact on reducing GHG emissions, divestment as an institutional strategy can contribute to increasing support for a climate agreement and effective climate policies in the medium and long term. In fact, it is possible that the divestment movement added to the social and political pressure that helped reach the Paris climate agreement in $2015^{24}$. This illustrates that not all of the 'for' and 'against' arguments have the same weight. One might grant a relatively high weight to pro-argument F1, i.e. the potential power of indirectly influencing climate policy. While opponents tend to focus on the rather negligible direct effects (e.g. A1 and A2), such direct effects are typically not claimed to be important by proponents. To draw more definite conclusions about what to expect from deliberate divestment strategies, further

${ }^{24} \mathrm{http} / / /$ climateanalytics.org/blog/2015/fossil-fuel-divestment-movement-gains-traction-in-the-run-up-to-theparis-climate-summit.html 
research in line with the suggestions in the final column of Table 1 is useful. Indeed, as fossil fuel divestment is a still emergent idea with tentative scientific foundations, more research can provide a clearer picture of what divestment could accomplish. This paper did not mean to provide a definite answer on this but provide a starting point for more academically oriented debate and research on fossil fuel divestment. The relevance of this is significant if it is indeed true what some argue (Weber, 2018), namely that divestment strategies, and more generally environmental concerns, in evaluating investment opportunities are on the rise. 
Table 1. Summary of arguments for and against fossil fuel divestment, and their connections

\begin{tabular}{|c|c|c|}
\hline Arguments & $\begin{array}{l}\text { Contrary } \\
\text { argument }\end{array}$ & Research needs \\
\hline \multicolumn{3}{|l|}{ for divestment } \\
\hline $\begin{array}{l}\text { F1. Its moral-political stance can } \\
\text { trigger debate and spur climate action }\end{array}$ & A4, A7 & $\begin{array}{l}\text { Previous divestment campaigns have demonstrated a political impact. But divestment is } \\
\text { complex and it is unclear what the precise effect is of divestment on policies like a carbon } \\
\text { tax, removal of fossil fuel subsidies or support of renewables. Several recent contributions } \\
\text { have analysed the divestment movement and its potential to contribute to climate change } \\
\text { mitigation (e.g. Ayling and Gunningham (2015) Linnenluecke et al. (2015), Gunningham } \\
\text { (2017) and Bergman (2018)). These studies find that the divestment movement has had } \\
\text { positive effects on the development of effective climate policies. }\end{array}$ \\
\hline $\begin{array}{l}\text { F2. Stigmatizing the fossil fuel industry } \\
\text { may diminish its power over policy }\end{array}$ & A2 & $\begin{array}{l}\text { Tillmann et al. (2015) argue that fossil fuel companies continue to hinder action on climate } \\
\text { change by exerting a powerful influence over policy and legislative processes. Kiyar and } \\
\text { Wittneben (2015) find that the divestment movement currently exerts an insignificant } \\
\text { influence on decision-making at the top of four German energy companies. More insight is } \\
\text { needed, though, about the extent to which lobbying negatively affects climate policy, } \\
\text { including negotiations for a climate agreement. In addition, research is needed into whether } \\
\text { stigmatizing the fossil fuel industry diminishes its power over policy. These issues could be } \\
\text { resolved by undertaking a questionnaire survey of or interviews with, policy-makers and } \\
\text { politicians. }\end{array}$ \\
\hline $\begin{array}{l}\text { F3. The exploration capacity of fossil } \\
\text { fuel companies can be reduced }\end{array}$ & A1 & See various suggestions in Ansar et al. (2013) and Ritchie and Dowlatabadi (2015b). \\
\hline $\begin{array}{l}\text { F4: Divestment can moderate systemic } \\
\text { financial risks of a 'climate bubble' }\end{array}$ & A1 & $\begin{array}{l}\text { Study the response of financial markets to divestment and an uncertain future for fossil } \\
\text { fuels, also given technological developments and intended policies in the context of the } \\
\text { Paris climate agreement. Macroevolutionary models with energy and financial sectors might } \\
\text { be suitable for this purpose (Safarzynska and van den Bergh, 2016, 2017). }\end{array}$ \\
\hline $\begin{array}{l}\text { F5. Divestment can stimulate re- } \\
\text { investment in low-carbon technologies }\end{array}$ & A1 & $\begin{array}{l}\text { Examine to what extent fossil fuel divestment leads to more investment in renewable } \\
\text { energy and energy efficiency policies. }\end{array}$ \\
\hline $\begin{array}{l}\text { F6. Divestment addresses an emerging } \\
\text { legal responsibility of investors to cope } \\
\text { with climate change risks }\end{array}$ & A6 & $\begin{array}{l}\text { While first contributions have addressed the issue (e.g. Sarang, Franta, 2017, 2016; } \\
\text { Richardson, 2017), the potential legal implications need further investigation. }\end{array}$ \\
\hline $\begin{array}{l}\text { F7. Divestment as an opportunity to } \\
\text { involve and educate young people }\end{array}$ & A3 & See F1 and A3. \\
\hline \multicolumn{3}{|l|}{ against divestment } \\
\hline $\begin{array}{l}\text { A1. It is symbolic and without economic } \\
\text { impact translating in reduced } \mathrm{CO}_{2} \\
\text { emissions }\end{array}$ & F3 & $\begin{array}{l}\text { Drawing parallels between the American anti-apartheid movement and today's 'fossil-free' } \\
\text { divestment campaign, Seidman (2015) finds that activists intend to provoke discussion } \\
\text { about transnational issues, raise moral questions, and mobilize political pressure. See } \\
\text { further remarks made under F4. }\end{array}$ \\
\hline $\begin{array}{l}\text { A2. Focus on fossil fuel companies } \\
\text { neglects the systemic nature of } \\
\text { emissions }\end{array}$ & F2 & $\begin{array}{l}\text { See remarks under F2 and F3. In addition, one might use 'ecological macroeconomics' } \\
\text { models, such as those in Dafermos et al. (2017) and Hardt et al. (2017), to study the } \\
\text { systemic impact of divestment. }\end{array}$ \\
\hline $\begin{array}{l}\text { A3. A potential negligible effect on } \\
\text { public support for climate policy }\end{array}$ & F1 & $\begin{array}{l}\text { As discussed under F1, recent scientific contributions suggest that the effect on public } \\
\text { support has been considerable. To further investigate the issue, a survey among citizens } \\
\text { could provide insight on how divestment affects their views on climate change and policy. }\end{array}$ \\
\hline $\begin{array}{l}\text { A4. Risk of backfire by drawing } \\
\text { attention away from more effective } \\
\text { climate action }\end{array}$ & F1 & $\begin{array}{l}\text { As discussed under F1, existing evidence suggests that divestment supports rather than } \\
\text { obstructs effective climate action. To further investigate this issue, it would be useful to } \\
\text { examine the behaviour of activists, lobbyists and policy-makers. }\end{array}$ \\
\hline $\begin{array}{l}\text { A5. Inconsistency: change others not } \\
\text { yourself, and continue carbon-intensive } \\
\text { consumption }\end{array}$ & - & $\begin{array}{l}\text { There is a need for behavioural, psychological and economic, research on inconsistencies } \\
\text { between stated and revealed preferences. }\end{array}$ \\
\hline $\begin{array}{l}\text { A6. It is questionable to apply subjective } \\
\text { norms to other people }\end{array}$ & F2 & $\begin{array}{l}\text { A questionnaire might be set out among citizens to see whether climate change is a } \\
\text { subjective norm or a commonly agreed moral issue. }\end{array}$ \\
\hline $\begin{array}{l}\text { A7. Representative role of institutions } \\
\text { and unwanted societal effects }\end{array}$ & $\mathrm{F} 4$ & $\begin{array}{l}\text { Schneider (2015) asks whether the legal framework for the anti-apartheid divestment } \\
\text { campaign in the 1980s is an appropriate model for divestment from fossil fuels. He } \\
\text { concludes that though divestment from fossil fuels may not mirror the anti-apartheid } \\
\text { divestment model, it does not create a breach of fiduciary duties for public pension plan } \\
\text { trustees. Likewise, Sarang (2015) argues that courts should recognize the special threat } \\
\text { posed by climate change to humanity and emphasizes the role of charitable and public } \\
\text { institutions to assure that investments account for climate change impacts. Trinks et al. } \\
\text { (2018) analyse the risk-adjusted return on investment portfolios with and without fossil fuel } \\
\text { companies over the period 1927-2015 and find that fossil-free investment does not seem to } \\
\text { impair financial performance. More insight into decision-making by large investors, } \\
\text { including universities, is needed to assess if such risks and effects influence their decision } \\
\text { making. }\end{array}$ \\
\hline
\end{tabular}




\section{References}

Ansar, A.; Caldecott, B. L.; Tilbury, J. (2013): Stranded Assets and the Fossil Fuel Divestment Campaign: What Does Divestment Mean for the Valuation of Fossil Fuel Assets? Smith School of Enterprise and Environment, University of Oxford.

Ayling, J. and Gunningham, N. (2017). Non-state governance and climate policy: the fossil fuel divestment movement. Climate Policy 17:2, 131-149.

Ayling, J. (2017). A Contest for Legitimacy: The Divestment Movement and the Fossil Fuel Industry. Law \& Policy, Vol. 39, No. 4.

Arabella Advisors (2016). The Global Fossil Fuel Divestment and Clean Energy Investment Movement. https://www.arabellaadvisors.com/wp-content/uploads/2016/12/Global_Divestment_Report_2016.pdf

Baker, M., J.C. Stein and J. Wurgler (2003). When does the market matter? Stock prices and the investment of equity-dependent firms. The Quarterly Journal of Economics 118(3): 969-1005.

Beer, C.T. (2016). Rationale of early adopters of fossil fuel divestment. International Journal of Sustainability in Higher Education. 17 (4) 506-519.

Bergman, N. (2018). Impacts of the Fossil Fuel Divestment Movement: Effects on Finance, Policy and Public Discourse. Sustainability, 10(7), 1-18.

Bratman, E, Brunette, K., Shelly, D.C. Nicholson, S. (2016). Justice is the goal: divestment as climate change resistance. Journal of Environmental Studies and Sciences.

Bowen, W. G. (2015): Demanding universities to divest is often bad policy.

http://www.washingtonpost.com/opinions/demanding-universities-to-divest-is-often-badpolicy/2015/03/27/1382fbe4-d401-11e4-ab77-9646eea6a4c7_story.html.

Brulle, R.J. (2014). Institutionalizing delay: foundation funding and the creation of U.S. climate change countermovement organizations. Climatic Change 122(4): 681-694.

Carbon Tracker Initiative (2011). Unburnable Carbon. Are the world's financial markets carrying a carbon bubble?

http://www.carbontracker.org/wp-content/uploads/2014/09/Unburnable-Carbon-Full-rev2-1.pdf.

Clarke, L., Jiang, K., Akimoto, K., Babiker, M., Blanford, G., Fisher-Vanden, K., Hourcade, J.C., Krey, V., Kriegler, E., Loschel, A., McCollum, D., Paltsev, S., Rose, S., Shukla, P.R., Tavoni, M., van der Zwann, B.C.C., van Vuuren, D.P., (2014). Chapter 6: Assessing Transformation Pathways, in: Edenhofer, O., Pichs-Madruga, R., Sokona, Y., Farahani, E., Kadner, S., Seyboth, K., Adler, A., Baum, I., Brunner, S., Eickemeier, P., Kriemann, B., Savolainen, J., Schlömer, S., Stechow, Von, C., Zwickel, T., Minx, J.C. (2014) (Eds.), Climate Change 2014: Mitigation of Climate Change. Climate Change. Contribution of Working Group III to the Fifth Assessment Report of the Intergovernmental Panel on Climate Change. Cambridge University Press, pp. 413-510.

Cleveland, C.J. and R. Reibstein (2015). The Path to Fossil Fuel Divestment for Universities: Climate Responsible Investment. Posted 18 Feb 2015, https://papers.ssrn.com/sol3/papers.cfm?abstract_id=2565941

Critchlow, A. (2015). Liberal green lobby will condemn BRICS to colonial servitude. The Telegraph, http://www.telegraph.co.uk/finance/newsbysector/energy/oilandgas/11545169/Liberal-green-lobby-willcondemn-BRICS-to-colonial-servitude.html

Dafermos, Y., Nikolaidi, M., Galanis, G. (2017). A stock-flow-fund ecological macroeconomic model. Ecological Economics 131: 191-207.

Davidson, C.; Kaufman, C. (2015). Is Reinvestment a Good Strategy for the Fossil Fuel Divestment Movement? Edited by Truthout.

http://www.truth-out.org/opinion/item/28694-is-reinvestment-a-good-strategy-for-the-fossil-fuel-divestmentmovement\#.

Davies, S.W. and Van Wesep, E.D. (2016). The Unintended Consequences of Divestment. http://dx.doi.org/10.2139/ssrn.2647729

Dietz, S.; Bowen, A.; Dixon, C.; Gradwell, P., (2016): 'Climate value at risk' of global financial assets. Nature Climate Change. doi:10.1038/nclimate2972 
Divest-Invest Global Movement (2014). Economic Drivers. Action Statement and Action Plan.

http://www.un.org/climatechange/summit/wp-content/uploads/sites/2/2014/09/FINANCING-Divest-InvestGlobal-Movement.pdf.

European Green Party (2014). The carbon bubble: The financial risk of fossil fuels and need for divestment. http://gef.eu/uploads/media/The_Price_of_Doing_Too_Little_Too_Late_.pdf

Evans-Pritchard, A. (2015): G20: fossil fuel fears could hammer global financial system.

http://www.telegraph.co.uk/finance/economics/11563768/G20-to-probe-carbon-bubble-risk-to-globalfinancial-system.html.

Exxon Mobile (2015). More on divestment: A letter to Tim Wirth.

http://www.exxonmobilperspectives.com/2014/11/06/more-on-divestment-a-letter-to-tim-wirth/

Fossil Free MIT (2014). The Fossil Fuel Industry's Role in Hindering Climate Change Action: Lobbying and Disinformation Against Science and Scientists.

http://www.fossilfreemit.org/wp-content/uploads/2014/08/FossilFreeMIT-Lobbying-Disinformation.pdf.

Fossil Free (2014). Fossil Fuel Divestment Communications Guide.

https://s3.amazonaws.com/s3.350.org/images/Fossil_Free_Communications_Guide_1.pdf.

Franta, B. (2014). Two Important Errors in the Fossil Fuel Divestment Debate: A Response to Rober Stavins. Edited by The Energy Collective.

http://theenergycollective.com/bafranta/2154576/two-important-errors-fossil-fuel-divestment-debateresponse-robert-stavins.

Franta, B. (2017). Litigation in the Fossil Fuel Divestment Movement. Law \& Policy, Vol. 39, No. 4.

Gapper, J. (2015). Fossil fuel campaigners play charades. Financial Times.

http://www.ft.com/intl/cms/s/2/399d8228-e1cf-11e4-bb7f-00144feab7de.html\#axzz3bEjBNmuW

Geczy, Christopher C., Robert F. Stambaugh, and David Levin. (2005). Investing in socially responsible mutual funds. Working Paper, University of Pennsylvania, Wharton.

Grady-Benson, J. (2014). Fossil Fuel Divestment: The Power and Promise of a Student Movement for Climate Justice. Pitzer Senior Theses.

http://scholarship.claremont.edu/cgi/viewcontent.cgi?article=1057\&context=pitzer_theses.

Green America (2013). Guide to Fossil Fuel Divestment - and Clean Energy Reinvestment.

http://www.greenamerica.org/PDF/FossilFree.pdf

Greenpeace (2014). Publications on industry lobbying against climate action and climate science.

http://www.greenpeace.org/international/Global/international/briefings/climate/2014/climate-

denialism/Annex-A.pdf

Gunningham (2017): Building Norms from the Grassroots Up: Divestment, Expressive Politics, and Climate Change. Law \& Policy, Vol. 39, No. 4

Hardt, L., O'Neill, D.W. (2017). Ecological Macroeconomic Models: Assessing Current Developments. Ecological Economics 134: 198-211.

Harvard Magazine (2013). Harvard Will Not Divest Fossil-Fuel Holdings.

http://harvardmagazine.com/2013/10/harvard-will-not-divest-fossil-fuel-holdings.

Healy, N., and Barry, J. (2017). Politicizing energy justice and energy system transitions: Fossil fuel divestment and a "just transition". Energy Policy, 108, 451-459.

Heede, R. (2013). Tracing anthropogenic carbon dioxide and methane emissions to fossil fuel and cement producers, 1854-2010. Climatic Change 122, 229-241.

Henriques, I., and P. Sadorsky (2017). Investor implications of divesting from fossil fuels. Global Finance Journal, in press. https://doi.org/10.1016/j.gfj.2017.10.004

Hong, H., and M. Kacperczyk. (2009). The price of sin: The effects of social norms on markets. Journal of Financial Economics 93: 15-36.

Hong Teoh, S. I. Welch and C.P.I Wazzan (1999). The Effect of Socially Activist Investment Policies on the Financial Markets: Evidence from the South African Boycott. The Journal of Business 72(1): 35-89. 
Hope, M. (2015). The Guardian's self-defeating climate campaign.

http://www.climate-hope.co.uk/2015/03/the-guardians-self-defeating-climate.html

HSBC (2013): Oil \& Carbon revisited. Value at risk from "unburnable" reserves.

http://www.documentcloud.org/documents/809475-hsbc-jan-2013-unburnable-reserves.html.

Hunt, C., O. Weber and T. Dordi (2016). A comparative analysis of the anti-Apartheid and fossil fuel divestment campaigns. Journal of Sustainable Finance and Investment 7(1): 64-81.

IEA (2013-2016): International Energy Agency, World Energy Outlook 2013-2016.

IPCC (2014) Climate Change 2014: IPCC Fifth Assessment Synthesis Report.

Approved Summary for Policymakers. http://www.ipcc.ch/pdf/assessment-report/ar5/syr/SYR_AR5_SPM.pdf/

Kiyar, D., Wittneben, B.B.F. (2015). Carbon as Investment Risk-The Influence of Fossil Fuel Divestment on Decision Making at Germany's Main Power Providers. Energies 8 (9), 9620-9639.

Krey, V., Luderer, G., Clarke, L., Kriegler, E. (2013). Getting from here to there - energy technology transformation pathways in the EMF27 scenarios. Climatic Change 123, 369-382.

Kumar, R., W.B. Lamb and R.E. Wokutch (2002). The End of South African Sanctions, Institutional Ownership, and the Stock Price Performance of Boycotted Firms: Evidence on the Impact of Social/Ethical Investing. Business and Society 41(2): 133-165.

Lavoie, J. (2015). Divestment Insufficient Without Government-Sponsored Emissions Reductions, Says New Report.

http://www.desmog.ca/2015/01/29/divestment-insufficient-without-government-sponsored-emissionsreductions-says-new-report

Leber, R. (2015). Divestment Won't Hurt Big Oil, and That's OK.

http://www.newrepublic.com/article/121848/does-divestment-work.

Lenferna, A. (2015). Divest-Invest: A Moral, Financial \& Economic Case for Fossil Fuel Divestment.

https://www.academia.edu/9667929/Divest-

Invest_A_Moral_Financial_and_Economic_Case_for_Fossil_Fuel_Divestment.

Lenferra, A. (2014). Why Fossil Fuel Divestment Is Working.

http://www.ethicsandinternationalaffairs.org/2014/why-fossil-fuel-divestment-is-working/.

Linnenluecke MK, Meath, C, Rekker, S, Sidhu, BK, \& Smith, T. 2015. Divestment from Fossil Fuel Companies: Confluence between Policy and Strategic Viewpoints. Australian Journal of Management.

Lisle, D. (2014). Unburnable Carbon: Bill MacKibben's frightening math.

http://www.knowtheflow.com/2014/unburnable-carbon-bill-mckibbens-frightening-math/.

Markowitz, E.M. and Shariff, A.F. (2012). Climate change and moral judgement. Nature Climate Change 2(3): 243-247.

McGlade, C.; Ekins, P. (2015). The geographical distribution of fossil fuels unused when limiting global warming to $2{ }^{\circ} \mathrm{C}$. Nature 517 (7533): 187-190. DOI: 10.1038/nature14016.

McKibben, B. (2012). Global warming's terrifying new math. Rolling Stone.

http://www.rollingstone.com/politics/news/global-warmings-terrifying-new-math-20120719

McKibben, B. (2016). How to stop the fossil fuel industry from wrecking our world.

https://www.ecowatch.com/bill-mckibben-how-to-stop-the-fossil-fuel-industry-from-wrecking-our-w1882154455.html

Mercure, J.-F., H. Pollitt, J.E. Viñuales, N.R. Edwards, P.B. Holden, U. Chewpreecha, P. Salas, I. Sognnaes, A. Lam and F. Knobloch (2018). Macroeconomic impact of stranded fossil fuel assets. Nature Climate Change, forthcoming, https://www-nature-com.vu-nl.idm.oclc.org/articles/s41558-018-0182-1

Meznar, M.B., D. Nigh, and C.C.Y. Kwok (2017a). Effect of Announcements of Withdrawal from South Africa on Stockholder Wealth. Academy of Management Journal 37(6): 1633-1648.

Meznar, M.B., D. Nigh, and C.C.Y. Kwok (2017b). Announcements of withdrawal from south africa revisited: Making sense of contradictory event study findings. Academy of Management Journal 41(6): 715-730. 
Morck, R., A. Shleifer, and R.W. Vishny (1990). The stock market and Investment: Is the market a sideshow? Brookings Papers on Economic Activity 21 (2): 157-216.

Moss, J. (2017). The Morality of Divestment. Law \& Policy, Vol. 39, Issue 4, pp. 412-428, 2017.

Murtha, P. (2015). Why universities must divest from oil stocks. Letter to the Editor, Washington Post. http://www.washingtonpost.com/opinions/why-universities-must-divest-from-oilstocks/2015/04/03/fc3a6b08-d887-11e4-bf0b-f648b95a6488_story.html

Oreskes, N.; Conway, E. M. (2010). Merchants of Doubt: How a Handful of Scientists Obscured the Truth on Issues from Tobacco Smoke to Global Warming. Bloomsbury Press.

Plantinga, A., and B. Scholtens (2016). The financial impact of divestment from fossil fuels. Research Report 16005-EEF, Research Institute SOM (Systems, Organisations and Management), University of Groningen.

Posnikoff, J.F. (1997). Disinvestment from south africa: they did well by doing good. Contemporary Economic Policy 15(1): 76-86.

Richardson, B.J. (2017). Divesting from Climate Change: The Road to Influence. Law \& Policy, Vol. 39, No. 4.

Ritchie, J. and Dowlatabadi, H. (2015a) Divest from the Carbon Bubble? Reviewing the Implications and Limitations of Fossil Fuel Divestment for Institutional Investors. Review of Economics \& Finance 5(2): 59-80

Ritchie, J., Dowlatabadi, H. (2015b). What Divesting May Yield: Revisiting "The Grasshopper and the Ant" in the Context of University Endowments. Journal of Environmental Investing 6, 51-74.

Ritchie, J. and Dowlatabadi, H. (2015c). Fossil Fuel Divestment: Reviewing Arguments, Implications \& Policy. Pacific Institute for Climate Solutions. Working paper.

http://pics.uvic.ca/sites/default/files/uploads/publications/Divestment\%20WP\%20Jan\%202015-FINAL.pdf

Roberts, D. (2015): College students are making global warming a moral issue. Here's why that scares people. http://www.vox.com/2015/4/29/8512853/fossil-fuel-divestment.

Rowe, J., Dempsey, J., Gibbs, P. (2016). The Power of Fossil Fuel Divestment (and its Secret) in A World To Win: Contemporary Social Movements and Counter-Hegemony. Co- edited by William K. Carroll and Kanchan Sarker. ARP Books, 2016.

Safarzynska, K., and J. van den Bergh (2016). Integrated crisis-climate policy: Macro-evolutionary modelling of interactions between technology, finance and energy systems. Technological Forecasting and Social Change 114: 119-137.

Safarzynska, K., and J. van den Bergh (2017). Financial stability at risk due to investing rapidly in renewable energy. Energy Policy 108: 12-20.

Sarang, S. (2016). Combating Climate Change Through a Duty to Divest. Columbia Journal of Law and Social Problems 49 (2) 296 - 341.

Schifeling, T., \& Hoffman, A. J. (2017). Bill McKibben's influence on US climate change discourse: Shifting fieldlevel debates through radical flank effects. Organization \& Environment, 1086026617744278

Schneider, N., (2015). Revisiting Divestment. Hastings Law J. 66 (2), 589-615.

Seidman, G.W. (2015). Divestment Dynamics: Mobilizing, Shaming, and Changing the Rules. Social Research: An International Quarterly (82 4).

Sinn, H.W. (2012). The Green Paradox: A Supply-Side Approach to Global Warming. The MIT Press, Cambridge, MA.

Stavins, R. N. (2014). Fossil Divestment: Warranted \& Wise? In Environmental law institute. http://scholar.harvard.edu/files/stavins/files/column_58.pdf

Stephens J.C., Palchak E., Reese B. (2017) Divestment and Investment: Strategic Financial Decisions in Higher Education to Promote Societal Change Toward Sustainability. In: Leal Filho W., Skanavis C., do Paço A., Rogers J., Kuznetsova O., Castro P. (eds) Handbook of Theory and Practice of Sustainable Development in Higher Education. World Sustainability Series. Springer, Cham 
Stoddart, H. (2014). Food, Fossil Fuels and Filthy Finance.

https://www.oxfam.org/sites/www.oxfam.org/files/file_attachments/bp191-fossil-fuels-finance-climatechange-171014-en.pdf.

Supran, G., Oreskes, N., 2017. Assessing ExxonMobil's climate change communications (1977-2014). Environ. Res. Lett. 12, 084019. doi:10.1088/1748-9326/aa815f

The Guardian (2014). Bank of England investigating risk of 'carbon bubble'.

http://www.theguardian.com/environment/2014/dec/01/bank-of-england-investigating-risk-of-carbon-bubble.

The Guardian (2015a). Vatican 'may' consider divestment from fossil fuels, despite pope's call to arms, http://www.theguardian.com/environment/2015/jul/01/vatican-may-consider-divestment-fromfossil-fuels-despite-popes-call-to-arms.

The Guardian (2015b). Nick Stern: Shell is asking us to bet against the world on climate change. http://www.theguardian.com/sustainable-business/2015/may/27/stern-shell-is-asking-us-to-betagainst-the-world-on-climate-change?CMP=new_1194\&CMP=

The Washington Post (2015). Why universities must divest from oil stocks. Letters to the editor. http://www.washingtonpost.com/opinions/why-universities-must-divest-from-oilstocks/2015/04/03/fc3a6b08-d887-11e4-bf0b-f648b95a6488_story.html.

Tillmann, T., Currie, J., Wardrope, A., McCoy, D. (2015). Fossil fuel companies and climate change: the case for divestment. BMJ-British Medical Journal 350. 10.1136/bmj.h3196.

Tollefson, J. (2015). Reality check for fossil-fuel divestment. Acacemics urge other ways to reduce carbon emissions. Nature (521): 16-17.

Trinks, A., Scholtens, B., Mulder, M., Dam, L., (2018). Fossil Fuel Divestment and Portfolio Performance. Ecological Economics 146, 740-748. doi:10.1016/j.ecolecon.2017.11.036

Truelove, H.B., Carrico, A.R., Weber E. U., Raimi . K.T. , Vandenbergh, M.P. (2014). Positive and negative spillover of pro-environmental behavior: An integrative review and theoretical framework. Global Environmental Change 29: 127-138.Tutu, D. (2014). We fought apartheid. Now climate change is our global enemy. The Guardian. http://www.theguardian.com/commentisfree/2014/sep/21/desmond-tutu-climatechange-is-the-global-enemy

Weber, O., T. Dordi and V. Saravade (2017). How divesting of fossil fuels could help save the planet. The Conversation, December 10, 2017. http://theconversation.com/how-divesting-of-fossil-fuels-could-help-savethe-planet-88147

Weber, O. (2018). Divestment Moves into the Mainstream: High-profile divestment announcements are influencing the share price of fossil fuels. Environmental and Energy, Centre for International Governance Innovation, January 15, 2018.

Wolak, Frank (2014). Universities Can Do Better Than Symbolism: A Revenue-Neutral Carbon Tax. SIEPR policy brief.

http://web.stanford.edu/group/fwolak/cgi-bin/sites/default/files/policy_brief_price_carbon_oct_2014.pdf. 